\title{
Customer Retention Strategies by mobile phone Service providers in Zimbabwe: Case of Masvingo City
}

\author{
${ }^{1}$ MoyoTalak, ${ }^{2}$ Makore Albert \\ Department of Management Studies. Great Zimbabwe University
}

\begin{abstract}
Customer retention is the hallmark of Relationship Marketing, which is the current buzz word and it is the basis of sustainable competitive advantage. In the context of heightening global competition, customer retention is the way to hedge a firm's market from competition. It is five times cheaper to market to retained customers than to acquire new customers. The purpose of this research is to analyze the retention strategies used by the Zimbabwean mobile phone service providers and determine factors that cause customer retention for Zimbabwean mobile service providers. A survey was conducted on 120 subscribers from the three mobile network subscribers using structured questionnaires. The questionnaires were analyzed using SPSS. Likert scales and descriptive data was used to determine frequencies. Chi-square was used to establish the relationship between retention variable factors and the customer category to establish the major determinants of retention. The Chi- square was obtained at $95 \%$ confidence level and at 68 degree of freedom. Pearson Product Moment Correlation was used to establish the relationship between the independent variable (retention factors) and dependent variable (customer satisfaction.)The results confirm that the variable factors observed have a positive impact on customer retention in the Zimbabwean mobile phone industry.
\end{abstract}

Keywords: Customer, customer retention, strategies, mobile phone providers

\section{Background}

\section{Introduction}

Tele-communication contributes significantly to the GDP, a contribution of $6 \%$. Since the dollarization of the Zimbabwean economy, there has been upsurge in the penetration rate within the mobile telecommunication industry. Penetration rate was standing at 40\% in 2009 which was regarded as the slowest rate in the world, but now stand at above $70 \%$, that for Econet Wireless said to hover around $90 \%$.

Mopane Advisory services in 2009 alluded that the industry was still at its growth stage. Douglas Mboweni the Econet CEO in October 2012 cited that the mobile phone subscription will reach its saturation in few months that would follow. His observation is quite correct judging from intensifying competition, teledensity by September 2012 (which is a measure of the number of active mobile phone subscriber's identity module cards and landlines as \% of the country's potential users.) This currently stands at $89.8 \%$. From 2011 penetration rate rose from $73.2 \%$ to $75.9 \%$ during the first quarter of 2012 and $89.8 \%$ by end of 2012 . This show shows a fast expansion rate within the industry.

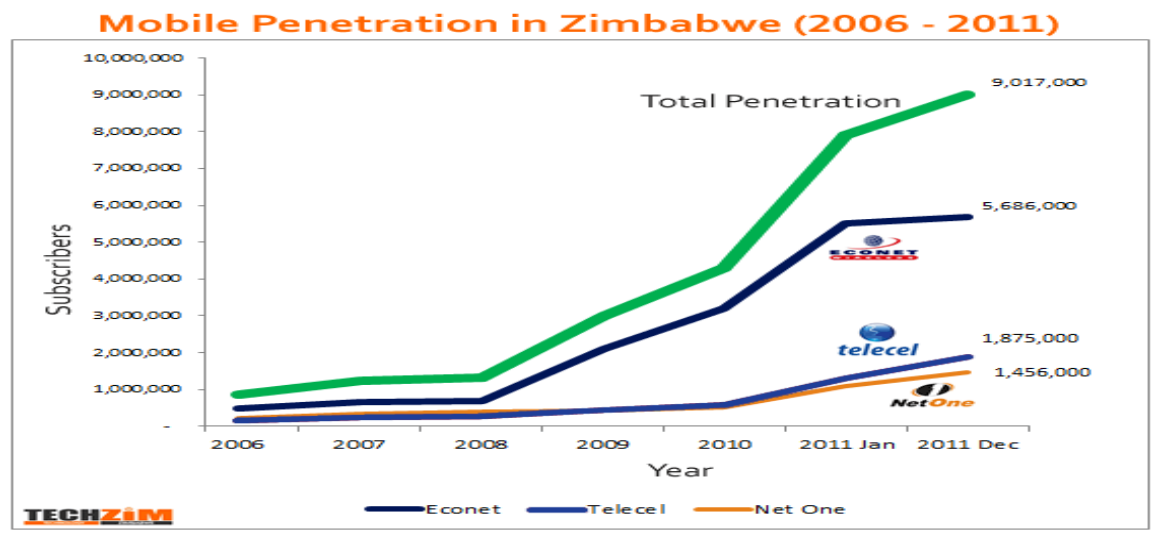

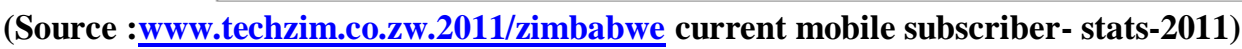

Within 2012 Econet is said to have gained 714000 mobile subscribers and Telecel 300000 subscribers. The rate for the rural community rose to $42.5 \%$ during the first quarter of 2012 .

The industry is characterized by intense competition, starting from 2009, and Econet Wireless has emerged the leader of the pack, dominated by only three players (Econet, Telecom and Net-One) . From 2009 mobile phone service providers started a massive campaign to distribute new lines on the market. Sim-card prices dropped 
drastically from as much as $\$ 70$ to $\$ 5$ and eventually dollar for two by 2011 . This gave impetuous to the penetration rate, since the majority could now afford the price of line.

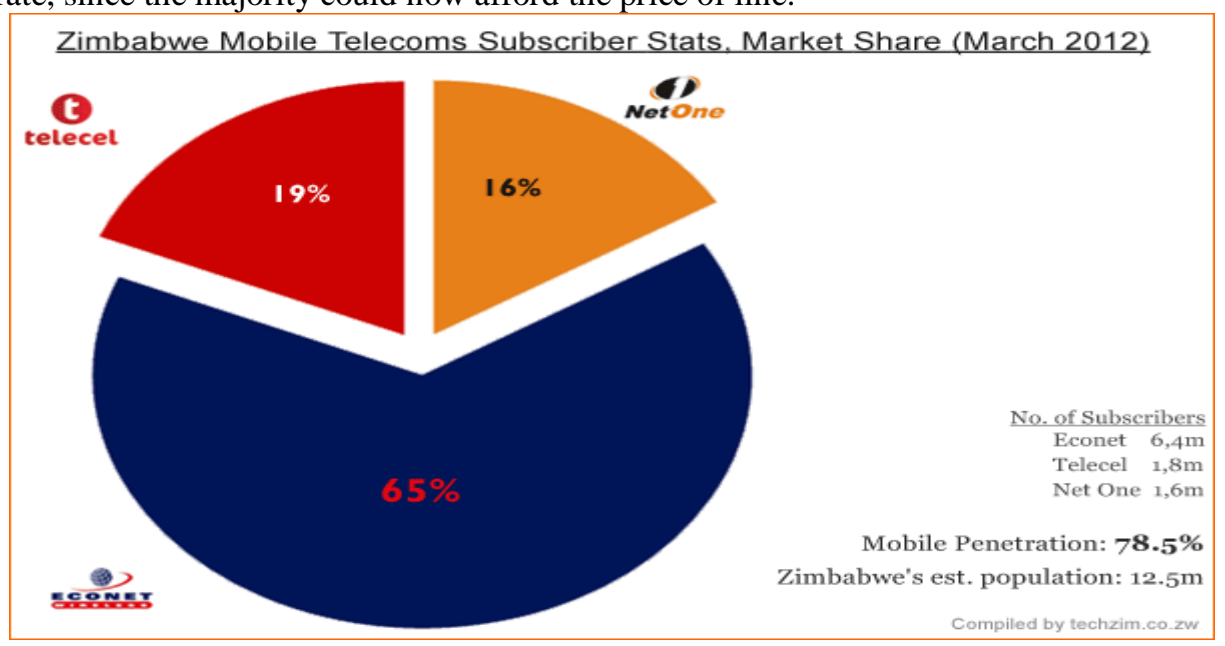

(Source: www.techzim.co.zw.2011/zimbabwe current mobile subscriber- stats-2011)

Tele-communication industry since 2009 has ploughed huge sums of money into recapitalization. For the last three years Econet invested about \$700million into the market for infrastructure development (POTRAZ, 2012). The competition has resulted in the increase of customer benefits, ranging from, expanded product ranges mainly and other promotional offers. At the same time the growth of internet service has brought a big threat to the industry. The VoIP such as the Face book, Skype and the Watsup which are lowly priced have become such a big threat to the industry.

\section{Statement of the problem}

With subscriber base nearing saturation and the rising competition from globalization, the mobile industry needs to adopt strategies that defend their market and understand the impact of their retention strategies on the customer and business performance in regard to their sales, market share, profitability and customer satisfaction. Understand how they can create sustainable competitiveness through retention strategies.

This is crucial to their hedging of the market against the local, international and global giants. With the lowering of the switching costs, sim-cards getting cheaper and cheaper, it has seen a lot customer churning in this industry. The players in this industry are spending huge sums of money on retention strategies as way to prevent the customer loss. Many have spent huge sums of money on infrastructure as way to better service delivery and retain customers and Econet has been leading the this regard.

Thus this research focuses on evaluating the retention strategies being employed by the mobile service providers in Zimbabwe. Determine the extent to which they have impacted on customer retention and satisfaction. Customer satisfaction is a critical to customer retention. A delighted customer will always return. There is also need to understand which retention strategies have had greatest impact on customer retention and which ones did not. This is important in identifying the strategies this industry needs to focus on most.

The research purposes to find out how the different age groups have reacted to these programs and which age groups most prone to switching and which one is not. How these different programs appeal to the different age groups.

\section{Literature Review}

In this literature review we discuss the various theories relating to customer retention focusing more on determinants of customer retention and the strategies organizations use to retain them. We will also show the relationship between customer satisfaction and retention.

\section{Definition of Customer Retention}

Customer retention may be viewed as both a behavioral and attitudinal factor (Ranaweera and Prabhu, 2003). Thus when exploring the concept we need to look at both the bavioural and attitudinal consequences of any intervention of the marketing effort. Behavioural variables include: customer contracts, transactional data, and customer response to the marketing effort and customer complaints. Attitudinal relates to customer satisfaction.

Many authors have written on customer retention and the benefits that accrue to the organization that adopt the concept. Reichheld (1996) argue that 5\% retention of customer's will translate to 35\% to95\% profits of the organization. This is the reason why the term has become such a buzz word to marketers. He further asserts that it five times cheaper to market to retain customer than to acquire new ones (Reichheld and Sasser, 1990). 
The simple definition by Buttle (2008) of customer retention is that it is the number of customers doing business with a firm at the end of a financial year expressed as a percentage of customers that were active at the beginning of the year.

From this definition customer retention is all about maintaining long-term relationship to generate a rebuy behviour. Relationship marketing philosophy as viewed by Gronroos(1994) aims to establish long-term relationship with the customer, to deepen the intimacy with the customer, providing a platform to fully understand customer needs and thus enhance customer value. The major aim is to maximize on customer life time value (customer wallet). You cannot keep an unprofitable customer just draining firm resources. Therefore customer retention is premised on customer contribution versus our investment in the customer.

\section{Customer Retention Theories.}

There are four main theories:

1) The Relationship Commitment Model by Sharma and Patterson (1999)

2) The Holistic Approach by Ranaweera and Prabhu (2003)

3) Conversion Model by Reichheld (1996)

4) Holistic Approach by Ranaweera and Neely (2003)

Sharma and Patterson 1999 (Relationship Commitment Model). The two identified the factors that influence relationship commitment or bonding are viewed as; communication effectiveness; technical Quality functional quality and trust. All the first three factors have an impact on trust, which in turn positively or negatively influence relationship commitment. Trust is defined by Sharma and Patterson (1990) as the belief that the service provider can be relied upon and that the provider will deliver the promise effectively, that they will meet their needs.

Crossby et al. (1990) define it as reliance on, or confidence in the person or process. Services are acts, deeds or performances .As a result the customer cannot evaluate the value / quality before consuming them, thus they generate high customer perceived risk. Thus the service marketer's effort should go towards boosting customer confidence in the service provider by providing physical proxies to tangibilise the services. The greater the trust the stronger the relationship. (Morgan and Hunt, 1994; Gummesson, 2008)

If a firm meets or exceeds customer needs then the customer will be satisfied. Customer satisfaction is viewed as a trust booster resulting from the customer brand experience, at times resulting from word of mouth. (Sharma and Patterson, 1999; Gronroos, 2004) they define Service quality as having two components Functional Quality and Technical quality. Technical is the outcome, the core benefits of the service. In the case of mobile telecommunication network availability, network coverage, clarity of network, easiness of connection, is the technical quality and this is what is delivered. On the other hand Functional quality is simply how the service is delivered. Mobile tele-communication is more of a remote encounter type of services, consumed mainly through the firm's infrastructure: the hand-sets used to receive the network, other gadgets used to access services from the network provider, modems for internet. It also involves the interaction between customers and the frontline staff, other technical support services they get from the service provider. Both technical and functional quality do affect customer perceived quality and finally satisfaction. In service marketing customers do only measure the outcome quality but the process quality is influential in their judgment of quality. Therefore the higher the customer perception of technical and functional quality the higher the trust and customer satisfaction and the relationship commitment (Sharma and Petterson, 1999)

\section{Communication Effectiveness}

It generally agreed by all societies that for any form relationship to thrive effective communication is a key ingredient (Gummerson, 2008). Partners in a relationship need to decide on how they will communicate, the type and amount of information they need to share. How frequently they must exchange the information. Communication must be two way process, where the organization can pass on information to inform customer of new products, promotions, advice on product usage, service recovery messages. On the other hand the customer can put forward their complaints, queries, and request for customization (their needs). The organization gather and analyse customer information from the all the customer touch points and this information is crucial for their marketing effort decisions. The greater the communication the greater the trust and the relationship commitment. ( Sharma and Patterson 1999; Gummerson ,2008).

\section{Holistic Approach to Satisfaction, Trust, and switching Barrier.}

Ranaweera and Prabhu (2003) proposed one of thetheories that looks at the combined effects on satisfaction, trust and switching barriers have on customer retention. It analyses both the independent and combined effects they have on customer retention. They content that satisfaction is key to customer retention. The basis for customer retention is customer delight through enhanced customer value. Any meaningful and 
sustainable competitive advantage should be based on customer delight (Zeithaml, Berry and Parasuraman, 1996; Ranaweera and Prabhu 2003).

\section{The conversion Model}

Reichheld (1996) argue that although satisfaction is the basis for customer retention, on its own it is not enough to retain customersas satisfied customers may defect. What matters most is customer loyalty, the highest degree of customer commitment to a relationship. Commitment arises out of the relationship benefits.

Reichheld (1996), identifies three factors that he believed influences commitment which are; level of customer involvement in the search process; attraction of alternatives -that is how customers compare firms offers with that of competitor. If customers perceive competitors' offers as having better value they will switch to competitor' products. The other factor identified is extent of ambivalence, which is the state when the customer is not completely converted to the firm's products, and is dissatisfied with some aspect of the product. They are not sure of what to do. At this stage customers will either leave or stay. It is time that the firm puts in place recovery system; one that tracks customer complaints and addresses them immediately. Research shows that customers whose complains have been effectively resolved are most likely to be retained by almost (95\%) than those whose complains are not addressed (Zeithaml, 1998). In retention strategies it is best to learn from the lost customer (reasons for defection) and improve your offers for the remaining customers.

\section{Price as a Determinant of customer Retention}

Price is the only $\mathrm{p}$ from the marketing mix that contribute directly to revenue, the other Ps are costs. In customer perceived value, price is important. (Buttle, 2008; Monroe, 1991; Zeithaml, 1998) According to Zeithaml (1998) some customers value low price. Most authors subscribe to the definition that price is perceived by customers to be a trade-off between the price paid and the quality they experience in consuming the product. Monroe (1991) defines customer value as the reduction in costs and a corresponding increase in the benefits that accrue to the customer.

Thus from the above argument price becomes an important factor in customer's evaluation of value. Zeithaml (1998) defines customer value as the overall assessment of the utility of a product based on a perception of what is received and has been paid. Thus it becomes an important factor in the value equation. Value $=$ Benefits /sacrifices. Price as a denominator if reduced will lead to more value (Monroe, 1991). Kollmann (2000) asserts that price is key in tele-communication business, particularly mobile phone industry. The price here include the cost of SIM card, recharge card, call rate, the internet charge rate, handset cost. Consumers tend to favour and subscribe to a service provider with the lowest call rates. Mobile phone firms benefit more if customer spends more time using their line (SIM card). That is how frequently and time customers use the particular SIM card (Kollmann, 2000; Adeleke and Aminu, 2012). Adeleke and Aminu further argue that high service quality is not a guarantee for customer attraction and retention. They argue that in the mobile industry price is quite a crucial factor and in Nigeria price has been used to attract new subscribers and retain customers. This works perfectly if the core services seem to be homogenous and not differentiated thus the price becomes a factor to induce customer switching either temporarily or permanently.

In Zimbabwe out of the 9 million subscribers, almost 50\% have more than two lines (SIM cards) either from different or the same service provider, but the other may not be active. Price thus in this case can be used to either retain or increase usage rate and frequency and ultimately the amount. Price satisfaction enhances customer value perception and there is direct relationship between price and value (Ralston, 2003). Price is a key factor in inducing re-buys behaviour depending on how price sensitive customer constituent may be (Hidalgo et al.2008).

\section{Drivers of Customer Retention/Strategies}

The first strategy and important one is delighting the customer. That is delivering the promise. It entails understanding customer value and designing delivery of the appropriate value proposition. Customers whose needs and expectations are met or exceeded are easy to retain. It is the delighted customer who will retain (Buttle, 2008). Firms or organisations should meet or exceed customer expectations on important attributes such as quality, service, price stability, and style.

Value adding program is the second strategy which includesloyalty schemes; these reward customers for their patronage. The more the customer spends the higher the rewards. Value derived is basically in five forms: cash value, redemption value-(how wide a range of rewards), inspirational value (how much does the customer want the value), relevance value, convenience value. The third strategy is customer clubs which offer both financial and social benefits to the customer.

Penetration marketing strategy comprise of cross-selling and up- selling tactics. It reduces customer search costs and provides much needed product range and convenience, one stop shop concept.It is about maximizing the value to the customer and optimizing the sales to current customer (share of wallet.) 
Customer service is another strategy that involves, constant communication with Customers, responding quickly to their needs, making products available, rendering advice and being visible.

Sound recovery system is one important customer retention strategy. There is no service which is fail prove no matter how you try to fail safe it. The organization can enhance satisfaction by putting in place a sound recovery system. Lastly there is sales promotion which is generally used to encourage trails and rebuy behavior. Relationship pricing would give value to the existing customer.

\section{Customer Satisfaction}

Satisfaction may be viewed as, an emotion (an affective response to service offers), meaning the extent to which the customer is happy with the service experience. How happy they are with certain mobile service providers. It also viewed as a fulfilment of the achievement of relevant goals. This entail the extent to which the service offers meet or exceeded customer needs. That is the extent to which customer are enabled to fulfil their communication goals by the mobile service provider. Satisfaction may also be viewed as a state, which is concerns the level of reinforcement or arousal, the extent to which it drives the customer towards acceptance or avoidance (Oliver, 1997; Parker and Mathews, 2001). Many authors have shown a strong correlation between customer satisfaction and retention (relationship longevity) and profitability (Aderson et al 1994; Bolton 1998; Bolton and Lemon, 1999; Gustafasson et al 2005). The bases for customer retention are enhanced customer value offers, which lead to customer delight. It is the delighted customer who is retained (Buttle, 2004).

\section{Research Methodology}

A descriptive research design was used to analyse the customer retention strategies employed the mobile service providers. The study was a survey conducted in Masvingo town of Zimbabwe on mobile phone subscribers, for the three mobile service providers Econet, Telcel and NetOne. A sample size of 120 subscribers was used based on convenience sampling, mainly mall- entercepts. Econet has $65 \%$ market share, Telcel has $19 \%$ and NetOne has 17\%. Research instrument used a structured questionnaire, which was personally delivered and collected. The questionnaire had three sections, the first section was mainly to solicit data on customer subscription and their generally usage rate of the SIM cards. The second part we used five point balanced likert scales on determinants of customer retention (service quality, customer care, price, communication, loyalty programs and other services offered (penetration marketing). The likert scale had rating 1 to 5 ( $1=$ very poor; $2=$ poor; $3=$ neutral; $4=$ good and $5=$ excellent)

The data for the study was analysed using SPSS and Excel. Chi-Square and Pearson Product Moment Correlations were used to test the hypothesis.

\section{Hypothesis}

$\mathrm{H} 1$ There is no correlation between service quality and customer satisfaction and retention in mobile phone market of Zimbabwe.

$\mathrm{H} 2$ There is no correlation between customer care and customer satisfaction and retention in mobile phone market of Zimbabwe.

H3 There is no correlation between price and customer satisfaction and retention in mobile phone market of Zimbabwe.

$\mathrm{H} 4$ There is no correlation between penetration marketing and customer satisfaction and retention in mobile market of Zimbabwe.

H5 There is no correlation between loyalty programs and customer satisfaction and retention in the mobile phone industry of Zimbabwe.

H6 There is no correlation between communication and customer satisfaction and retention in the mobile phone market of Zimbabwe.

\section{Results}

Table 1: Cell phone line or lines

\begin{tabular}{|l|l|l|l|l|l|}
\hline & & Frequency & Percent & $\begin{array}{l}\text { Valid } \\
\text { Percent }\end{array}$ & Cumulative Percent \\
\hline Valid & Econet & 63 & 52.5 & 52.5 & 52.5 \\
\hline & Telecel & 1 & 0.8 & 0.8 & 53.3 \\
\hline & Netone & 3 & 2.5 & 2.5 & 55.8 \\
\hline & Econet and telecel & 17 & 14.2 & 14.2 & 70 \\
\hline & Econet and Netone & 15 & 12.5 & 12.5 & 82.5 \\
\hline & Telecel and Netone three & $\mathbf{2 0}$ & $\mathbf{0 . 8}$ & $\mathbf{0 . 8}$ & $\mathbf{8 3 . 3}$ \\
\hline $\begin{array}{l}\text { All } \\
\text { Econet,Telecel,Netone) }\end{array}$ & 16.7 & 16.7 & 100 \\
\hline & Total & 120 & 100 & 100 & \\
\hline
\end{tabular}


A total of 53\% of respondents use econet only but there is also a number of subscribers who have econet and other lines as well. Total subscription for Econet lines is 79.2\%

Table 2: Descriptive Statistics on frequency of use

\begin{tabular}{|l|l|l|l|l|l|l|l|}
\hline \multicolumn{9}{|c}{} & Econet & Netone & Telecel \\
\hline & & Frequency & Percent & Frequency & Percent & Frequency & Percent \\
\hline Valid & 0 & 6 & 5 & 80 & 66.7 & 80 & 66.7 \\
\hline & 24 hrs per day & 86 & 71.7 & 19 & 15.8 & 9 & 7.5 \\
\hline & Once a week & 1 & 0.8 & 6 & 5.0 & 8 & 6.7 \\
\hline & Twice a week & 1 & 0.8 & - & - & - & - \\
\hline & Occationally & 24 & 20 & 15 & 12.5 & 23 & 19.2 \\
\hline & Not at all & 2 & 1.7 & - & - & - & - \\
\hline & Total & 120 & 100 & 120 & 100 & 100 & 100 \\
\hline
\end{tabular}

Table 2 shows the results on frequency of use by subscribers for the three networksand Econet has a high usage rate of $71.7 \%$ in 24 hours category. The occasionally usage can be attributed to subscribers who have either an Econet line as well as Netone or Telecel line. The least used line is Telecel with $7.5 \%$ in the 24 hour category. This is in line with Potraz's observations which show that Econet has a 65\% market share (6.4 million subscribers).

Table 3: Descriptive Statistics on recharge amounts per day

\begin{tabular}{|l|l|l|l|l|l|}
\hline & $\mathrm{N}$ & Minimum & Maximum & Mean & Std. Deviation \\
\hline Telecel recharge & 120 & .00 & 5.00 & .3417 & .72756 \\
Netone recharge & 120 & .00 & 3.00 & .3333 & .55509 \\
Econet recharge & 120 & .00 & 6.00 & 1.8583 & 1.39203 \\
Valid N (list wise) & 120 & & & & \\
\hline
\end{tabular}

The average recharge for Econet is $\$ 1.86$ per day and that for Telecel is $\$ 0.34$ and Netone is $\$ 0.33$. The monthly individual customer contribution is therefore approximately (1.86 x 30) $\$ 56.00$ and this reveals a high customer contribution in line with the Customer Lifetime Value (CLV). The results in the Table 3 show that there a high usage of Econet lines (simcard), despite a standard deviation of 1.39203, the variability indicates a minimum daily recharge of 0.46 daily.

\section{Hypothesis Testing}

Table 4 Chi-square tests

\begin{tabular}{|c|c|c|c|c|c|c|c|c|c|c|c|c|}
\hline & \multicolumn{5}{|c|}{ Customer ratings } & $\begin{array}{l}\text { Row } \\
\text { total }\end{array}$ & & & & & & Chi-square \\
\hline & 1 & 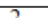 & 3 & 4 & 5 & & 7 & 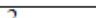 & 3 & 4 & 5 & \\
\hline $\begin{array}{l}\text { Keasons } \\
\text { retention }\end{array}$ for customer & 1 & 2 & 3 & 4 & J & & 1 & 2 & 3 & 4 & J & \\
\hline Econet network efficiency & 7 & 1 & 18 & 32 & 48 & 106 & 11.17838 & 5.950682 & 17.07345 & 23.80273 & 47.99475341 & 8.553864 \\
\hline Econet network coverage & 1 & 4 & 10 & 37 & 49 & 101 & 10.6511 & 5.66999 & 16.2681 & 22.67996 & 45.73084995 & 20.92728 \\
\hline Econet use by many people & 6 & 0 & 9 & 19 & 67 & 101 & 10.6511 & 5.66999 & 16.2681 & 22.67996 & 45.73084995 & 21.43745 \\
\hline $\begin{array}{l}\text { Econet handling of complaints } \\
\text { and queries }\end{array}$ & 5 & 4 & 27 & 31 & 43 & 110 & 11.60021 & 6.175236 & 17.71773 & 24.70094 & 49.80587618 & 11.92087 \\
\hline $\begin{array}{l}\text { Econet service shops for } \\
\text { support help }\end{array}$ & 5 & 5 & 15 & 27 & 54 & 106 & 11.17838 & 5.950682 & 17.07345 & 23.80273 & 47.99475341 & 4.999395 \\
\hline $\begin{array}{l}\text { Econet availability of recharge } \\
\text { cards }\end{array}$ & 4 & 1 & 3 & 11 & 87 & 106 & 11.17838 & 5.950682 & 17.07345 & 23.80273 & 47.99475341 & 58.9147 \\
\hline Econet call charges & 12 & 15 & 35 & 23 & 24 & 109 & 11.49475 & 6.119098 & 17.55666 & 24.47639 & 49.35309549 & 43.35533 \\
\hline Econet sim card fees & 10 & 7 & 17 & 19 & 49 & 102 & 10.75656 & 5.726128 & 16.42917 & 22.90451 & 46.18363064 & 1.193786 \\
\hline Econet prices of services & 8 & 7 & 25 & 27 & 40 & 107 & 11.28384 & 6.006821 & 17.23452 & 24.02728 & 48.4475341 & 6.45957 \\
\hline $\begin{array}{lll}\begin{array}{l}\text { Econet } \\
\text { access }\end{array} & \text { unlimited internet } \\
\end{array}$ & 6 & 4 & 19 & 34 & 43 & 106 & 11.17838 & 5.950682 & 17.07345 & 23.80273 & 47.99475341 & 8.144111 \\
\hline $\begin{array}{lll}\begin{array}{l}\text { Econet } \\
\text { services }\end{array} & \text { money } & \text { transfer } \\
\end{array}$ & 5 & 2 & 13 & 21 & 68 & 109 & 11.49475 & 6.119098 & 17.55666 & 24.47639 & 49.35309549 & 15.16413 \\
\hline $\begin{array}{l}\text { Econet } \\
\text { bankingservices,payment of } \\
\text { bills }\end{array}$ & 13 & 3 & 21 & 19 & 51 & 107 & 11.28384 & 6.006821 & 17.23452 & 24.02728 & 48.4475341 & 3.775173 \\
\hline Econet bonus call points & 28 & 18 & 19 & 23 & 21 & 109 & 11.49475 & 6.119098 & 17.55666 & 24.47639 & 49.35309549 & 63.26428 \\
\hline Econet text bonuses & 10 & 9 & 22 & 22 & 44 & 107 & 11.28384 & 6.006821 & 17.23452 & 24.02728 & 48.4475341 & 3.534593 \\
\hline Econet advance airtime & 52 & 11 & 14 & 12 & 14 & 103 & 10.86201 & 5.782267 & 16.59024 & 23.12907 & 46.63641133 & 189.1098 \\
\hline $\begin{array}{l}\text { Econet information updates to } \\
\text { cell phone users }\end{array}$ & 3 & 3 & 11 & 22 & 72 & 111 & 11.70567 & 6.231375 & 17.8788 & 24.9255 & 50.25865687 & 20.54523 \\
\hline Econet toll free numbers & 19 & 8 & 18 & 23 & 33 & 101 & 10.6511 & 5.66999 & 16.2681 & 22.67996 & 45.73084995 & 11.23479 \\
\hline Econet service shops & 7 & 5 & 11 & 26 & 56 & 105 & 11.07293 & 5.894544 & 16.91238 & 23.57817 & 47.54197272 & 5.454288 \\
\hline & 201 & 107 & 307 & 428 & 863 & 1906 & & & & & Chi-square & 497.9886 \\
\hline & & & & & & & & & & & $\begin{array}{l}\text { Chi-square } \\
\text { critical }\end{array}$ & \\
\hline & $\begin{array}{l}\text { p- } \\
\text { value } \\
0.05\end{array}$ & & & & & & & & & & & \\
\hline
\end{tabular}


The Table 4 above shows the observed frequencies and calculated expected frequencies for each variable and a chi=square value was calculated for each variable. A total of eighteen variables were used and these were further categorised in to six classes as follows:

1. Service quality (Econet network efficiency, Econet network coverage, Econet use by many people)

2. Customer care (Econet handling of complaints and queries, Econet service shops for support help, Econet availability of recharge cards)

3. Pricing (Econet call charges, Econet sim card fees, Econet prices of services)

4. Penetration marketing / Other services (Econet unlimited internet access, Econet money transfer services, Econet banking services and payment of bills)

5. Loyaltyprogrammes (Econet bonus call points, Econet text bonuses, Econet advance airtime)

6. Communication (Econet information updates to cellphone users, Econet tollfree numbers, Econet service shops)

The Chi-square value forall eighteen (18) variables computed is (497.9886) at 68 degrees of freedom and this was calculated at $95 \%$ confidence interval. $(\mathrm{p}=0.05)$

1) $H_{1}$ There is no correlation between service quality and customer satisfaction and retention in mobile phone market of Zimbabwe.

Table 5.Chi-square tests for service quality.

\begin{tabular}{|l|l|}
\hline $\begin{array}{l}\text { Reasons for customer } \\
\text { retention }\end{array}$ & \\
\hline Service quality & Chi-square \\
\hline $\begin{array}{l}\text { Econet network } \\
\text { efficiency }\end{array}$ & 8.553864 \\
\hline $\begin{array}{l}\text { Econet network } \\
\text { coverage }\end{array}$ & 20.92728 \\
\hline $\begin{array}{l}\text { Econet use by many } \\
\text { people }\end{array}$ & 21.43745 \\
\hline Combined chi-square & 50.918594 \\
\hline
\end{tabular}

\section{$d f .=8$ Chi-square value $=15.51$}

Since the chi-square value of 50.918594 is greater than 15.51 therefore we reject thehypothesis. Servicequality has an impact on customer retention as noted in our results which show that network efficiency, network coverage and the number of subscribers influences customer retention.

Table 6: Service quality and customer satisfaction correlation

\begin{tabular}{|c|c|c|c|c|}
\hline & $\begin{array}{l}\text { Service } \\
\text { quality }\end{array}$ & $\begin{array}{l}\text { Econet } \\
\text { network } \\
\text { efficiency }\end{array}$ & $\begin{array}{l}\text { Econet } \\
\text { network } \\
\text { coverage }\end{array}$ & $\begin{array}{l}\text { Econet use } \\
\text { by } \\
\text { meople }\end{array}$ \\
\hline $\begin{array}{l}\text { Customer } \\
\text { satisfaction } \\
\text { with } \\
\text { Econet }\end{array}$ & $\begin{array}{l}\text { Pearson } \\
\text { Correlation }\end{array}$ & $.484(* *)$ & $.348(* *)$ & $.306\left(^{* *}\right)$ \\
\hline & $\begin{array}{l}\text { Sig. } \\
\text { tailed) }\end{array}$ & 0 & 0 & 0.001 \\
\hline & $\mathrm{N}$ & 120 & 119 & 120 \\
\hline
\end{tabular}

** Correlation is significant at the 0.01 level (2-tailed).

The relationship of service quality and customer satisfaction as denoted by the results in Table 6 which shows that there is a low to moderate relationship between the variables. The correlation coefficients of Econet network efficiency and customer satisfaction is (0.484) and this considered as a moderate relationship. Also there is a moderate relationship between Econet network coverage and customer satisfaction as denoted by the correlation coefficient of (0.348). The number of subscribers for a particular service has no influence on customer retention as shown by correlation coefficient value (0.306) which is a weak relationship. Therefore, using overall results in Table 6, we reject the hypothesis. Service quality has an impact on customer retention. In support the following researchers note that, the higher the customer perception of technical and functional quality the higher the trust and customer satisfaction and the relationship commitment (Sharma and Petterson, 1999)

2) $\mathrm{H}_{2}$ There is no correlation between customer care and customer satisfaction and retention in mobile phone market of Zimbabwe. 
Table 7:Chi-square tests for customer care.

\begin{tabular}{|l|l|}
\hline $\begin{array}{l}\text { Reasons for customer } \\
\text { retention }\end{array}$ & \\
\hline Customer care & Chi-square \\
\hline $\begin{array}{l}\text { Econet handling of } \\
\text { complaints and } \\
\text { queries }\end{array}$ & 11.92087 \\
\hline $\begin{array}{l}\text { Econet service shops } \\
\text { for support help }\end{array}$ & 4.999395 \\
\hline $\begin{array}{l}\text { Econet availability of } \\
\text { recharge cards }\end{array}$ & 58.9147 \\
\hline Combined chi-square & 75.834965 \\
\hline
\end{tabular}

\section{$d f .=8$ Chi-square value $=15.51$}

Since the chi-square value of 75.834965 is greater than 15.51 therefore we reject thehypothesis. Customer care is critical in the retention process and this is shown by the fact that customers whose complaints have been effectively resolved are most likely to be retained by almost (95\%) than those whose complaints are not addressed (Zeithaml, 1998).

Table 8: Customer care and customer satisfaction correlation

\begin{tabular}{|c|c|c|c|c|}
\hline & $\begin{array}{l}\text { Customer } \\
\text { care }\end{array}$ & $\begin{array}{l}\text { Econet } \\
\text { handling of } \\
\text { complaints } \\
\text { and queries }\end{array}$ & $\begin{array}{l}\text { Econet } \\
\text { service } \\
\text { shops for } \\
\text { support } \\
\text { help }\end{array}$ & $\begin{array}{l}\text { Econet } \\
\text { availability } \\
\text { of } \\
\text { recharge } \\
\text { cards }\end{array}$ \\
\hline $\begin{array}{l}\text { Customer } \\
\text { satisfaction } \\
\text { with } \\
\text { Econet }\end{array}$ & $\begin{array}{l}\text { Pearson } \\
\text { Correlation }\end{array}$ & $.371(* *)$ & $.475(* *)$ & $.469(* *)$ \\
\hline & $\begin{array}{l}\text { Sig. } \\
\text { tailed) }\end{array}$ & 0 & 0 & 0 \\
\hline
\end{tabular}

The relationship of customer satisfaction and customer care is moderate as shown by the results in the above Table 8.The correlation coefficient between Econet handling of complaints and customer satisfaction is (0.371)denoting a weak relationship. Econet service shops and customer satisfaction have a moderate relationship as shown by a positive moderate correlation coefficient value (0.475).Econet availability of recharge cards and customer satisfaction also has moderate relationship (0.469) and the overall statiscal significance of this relationship is $(0)$. Therefore we reject the hypothesis that, there is no correlation between customer care and customer satisfaction and retention in mobile phone market of Zimbabwe.

3) $\mathrm{H}_{3}$ There is no correlation between price and customer satisfaction and retention in mobile phone market of Zimbabwe.

Table 9: Chi-square tests for Pricing.

\begin{tabular}{|l|l|}
\hline $\begin{array}{l}\text { Reasons for customer } \\
\text { retention }\end{array}$ & \\
\hline Pricing & Chi-square \\
\hline Econet call charges & 43.35533 \\
\hline Econet sim card fees & 1.193786 \\
\hline $\begin{array}{l}\text { Econet prices of } \\
\text { services }\end{array}$ & 6.45957 \\
\hline Combined chi-square & 51.008686 \\
\hline
\end{tabular}

\section{$d f .=8$ Chi-square value $=15.51$}

Since the chi-square value 51.008686 is greater than 15.51 therefore we reject the hypothesis. Pricing is a key factor in retention since it is an important factor in customer's evaluation of value. Zeithaml (1998) defines customer value as the overall assessment of the utility of a product based on a perception of what is received and has been paid. Value is = Benefits / sacrifices. Price as the denominator if reduced will lead to high benefits (Monroe 1991). 


Table 10: Pricing and customer satisfaction correlation
\begin{tabular}{|l|l|l|l|l|}
\hline \multicolumn{1}{|c|}{ Pricing } & $\begin{array}{l}\text { Econet call } \\
\text { charges }\end{array}$ & $\begin{array}{l}\text { Econet sim card } \\
\text { fees }\end{array}$ & $\begin{array}{l}\text { Econet prices of } \\
\text { services }\end{array}$ \\
\hline $\begin{array}{l}\text { Customer } \\
\text { satisfaction } \\
\text { Econet }\end{array}$ \\
\hline with & $\begin{array}{l}\text { Pearson } \\
\text { Correlation }\end{array}$ & $.439(* *)$ & $.358(* *)$ & $.436(* *)$ \\
\hline$* *$ & Sig. (2-tailed) & 0 & 0 & 0 \\
\hline
\end{tabular}

The correlation coefficient between customer satisfaction and Econet call charges is (0.439), denoting a moderate relationship, Econet sim card fees and customer satisfaction (0.358); Econet prices of other services and customer satisfaction (0.436) and the overall statistical significant is $(0)$, therefore we reject the hypothesis. Pricing has an influence on customer retention and usage rate.

4) $H_{4}$ There is no correlation between penetration marketing and customer satisfaction and retention in mobile market of Zimbabwe.

Table 11:Chi-square tests for other services availability

\begin{tabular}{|l|l|}
\hline Reasons for customer retention & \\
\hline Other services availability & Chi-square \\
\hline $\begin{array}{l}\text { Econet unlimited internet } \\
\text { access }\end{array}$ & 8.144111 \\
\hline Econet money transfer services & 15.16413 \\
\hline $\begin{array}{l}\text { Econet } \\
\text { bankingservices,payment of } \\
\text { bills }\end{array}$ & 3.775173 \\
\hline Combined chi-square & 27.083414 \\
\hline
\end{tabular}

\section{$d f .=8$ Chi-square value $=15.51$}

As can be noted from the results in Table 11 all the variable values are less than the chi square value (15.51)i.e. Other service availability $(8.144111<15.51)$; Internet access $(15.16413<15.51)$; Ecocash and electronic bill payment, and banking $(3.775173<15.51)$ rendering the factors insignificant. But the combined chi-square value (27.083414 > 15.51) makes them significant, showing there is some relationship. We can therefore reject the hypothesis. The factors are key for customer retention for the Zimbabwean mobile phone market, therefore we reject the hypothesis. These services are mainly technology based and it is likely that they are mainly enjoyed by a few, the youths, and educated class that have no technology inertia.

Table 12: Customersatisfaction and other services

\begin{tabular}{|c|c|c|c|c|}
\hline \multicolumn{5}{|l|}{ Correlations } \\
\hline & $\begin{array}{l}\text { Other } \\
\text { services } \\
\text { available }\end{array}$ & $\begin{array}{l}\text { Econet } \\
\text { unlimited } \\
\text { internet } \\
\text { access }\end{array}$ & $\begin{array}{l}\text { Econet } \\
\text { money } \\
\text { transfer } \\
\text { services }\end{array}$ & $\begin{array}{l}\text { Econet banking } \\
\text { services, } \\
\text { payment of bills }\end{array}$ \\
\hline $\begin{array}{l}\text { Customer } \\
\text { satisfaction } \\
\text { with } \\
\text { Econet } \\
\end{array}$ & $\begin{array}{l}\text { Pearson } \\
\text { Correlation }\end{array}$ & $.419(* *)$ & $.454(* *)$ & $.428(* *)$ \\
\hline & Sig. (2-tailed) & 0 & 0 & 0 \\
\hline & $\mathrm{N}$ & 120 & 119 & 120 \\
\hline
\end{tabular}

** Correlation is significant at the 0.01 level (2-tailed).

The results from table12 confirm the findings in table 11 that the variable factors in question have an impact on retention. Results show that there is a moderate relationship between other services available and satisfaction. The correlation value between customer satisfaction and Other services Availableis (0.419); and that of satisfaction to Internet Access (0.454) ;satisfaction to Econet banking services, and bill payment $(0.428)$ and the statistical significance of the correlation is $(0)$.

Therefore we reject the hypothesis; these factors do have an impact on customer retention. Previous researches have shown strong relationship between retention and satisfaction. Satisfaction is an antecedent of customer retention. It is the delighted customer who is retained. 
5) $\mathrm{H}_{5}$ There is no correlation between loyalty programs and customer satisfaction and retention in the mobile phone industry of Zimbabwe.

Table 13 Chi-square tests for loyalty programmes

\begin{tabular}{|l|l|}
\hline Reasons for customer retention & \\
\hline Loyalty programmes & Chi-square \\
\hline Econet bonus call points & 63.26428 \\
\hline Econet text bonuses & 3.534593 \\
\hline Econet advance airtime & 189.1098 \\
\hline Combined chi-square & 255.908673 \\
\hline
\end{tabular}

\section{DF. $=8$ Chi-square value $=15.51$}

The results from table 13 reveal that generally these variable factors are significant, deducing from the overall chi- square (255.908673> 15.51). Taken individually the result show a significant except one. Econet bonus points $(63.26428>15.51$; Econet text bonus $(3.534593<15.51)$; Econet advance airtime $(189.908673>$ 15.51). We reject the hypothesis the variable factors have an impact on customer retention.

Table14: Customer satisfaction with Econet and loyalty programmes

\begin{tabular}{|l|c|c|c|c|}
\hline \multicolumn{2}{|c|}{ Correlations } & Bonus call points & Text bonuses & \multicolumn{1}{c|}{$\begin{array}{l}\text { Advance } \\
\text { airtime }\end{array}$} \\
\hline & & & & $.311(* *)$ \\
$\begin{array}{l}\text { Customer } \\
\text { satisfaction with } \\
\text { Econet }\end{array}$ & $\begin{array}{l}\text { Pearson } \\
\text { Correlation }\end{array}$ & $.356(* *)$ & $.474(* *)$ & 0 \\
\hline & Sig. (2-tailed) & 0 & 0 & 120 \\
\hline
\end{tabular}

The Pearson correlations coefficient between loyalty programs and customer satisfaction in table 14 is $(0.356)$ revealing a moderate relationship. The correlation value between customer satisfaction and bonus call pointsis (0.474) showing a moderate relationship, and that of advance airtime and customer satisfaction is $(0.311)$, showing a weak relationship and the statistical significant for all three variable is $(0)$. Therefore we reject the hypothesis, the variable factors have an impact on customer retention.Loyalty programs besides influencing continuity of usage of the mobile line, and they also reduce customer costs by winning bonus call points and free texts messages. The discussion on price revealed that costs are critical in their influence on customer's evaluation of quality. A cost reduction would be viewed as an increase to benefits

6) $H_{6}$ There is no correlation between communication and customer satisfaction and retention in the mobile 7) phone market of Zimbabwe.

Table 15 Chi-square tests for communication

\begin{tabular}{|l|l|}
\hline Reasons for customer retention & \\
\hline Communication & Chi-square \\
\hline $\begin{array}{l}\text { Econet information updates to } \\
\text { cellphone users }\end{array}$ & 20.54523 \\
\hline Econet tollfree numbers & 11.23479 \\
\hline Econet service shops & 5.454288 \\
\hline Combined chi-square & 37.234308 \\
\hline
\end{tabular}

$d f .=8$ Chi-square value $=15.51$

The results from the table show that the factors of retention tested are significant judging from the overall chi square of $(37.234308<15.51)$. Therefore we reject the hypothesis for any relation to thrive communication is critical where the parties need to make a decision on who to communicate with, the amount and type of information to communicate (what) and how often they need to communicate. (Gummesson, 2009). Communication is crucial for the development of trust a critical point in relationship sustenance of a relationship. 
Customer Retention Strategies by mobile phone Service providers in Zimbabwe: Case of Masvingo

Table 16: Customer satisfaction and communication

\begin{tabular}{|c|c|c|c|c|}
\hline \multicolumn{5}{|l|}{ Correlations } \\
\hline & Communication & $\begin{array}{l}\text { Econet information } \\
\text { update }\end{array}$ & $\begin{array}{ll}\text { Tool } & \text { free } \\
\text { numbers }\end{array}$ & $\begin{array}{l}\text { Service } \\
\text { shops }\end{array}$ \\
\hline \multirow[t]{3}{*}{$\begin{array}{l}\text { Customer } \\
\text { satisfactio } \\
\mathrm{n} \quad \text { with } \\
\text { Econet }\end{array}$} & $\begin{array}{l}\text { Pearson } \\
\text { Correlation }\end{array}$ & $.673(* *)$ & $.281(* *)$ & $.503(* *)$ \\
\hline & Sig. (2-tailed) & 0 & 0 & 0 \\
\hline & $\mathrm{N}$ & 120 & 119 & 120 \\
\hline
\end{tabular}

From table 16 the correlation coefficient for customer satisfaction and Econet information update is $(0.673)$ denoting a strong relationship between the variables; use of tollfree numbers and customer satisfaction is (0.281), this shows a weak relationship, and that of customer satisfaction and availability of service shops is ( $0.503)$ depicting a moderate relationshipand the overall statistical significant of all three variables is (0) Therefore we reject the hypothesis that there is no correlation between communication and customer satisfaction and retention in the mobile phone market of Zimbabwe.

Table 17: Summary of Hypothesis Tests

\begin{tabular}{|l|l|l|}
\hline & Hypothesis & Status \\
\hline H1 & $\begin{array}{l}\text { There is no correlation between service quality and customer satisfaction and retention } \\
\text { in mobile phone market of Zimbabwe. }\end{array}$ & Rejected \\
\hline H2 & $\begin{array}{l}\text { There is no correlation between customer care and customer satisfaction and retention in } \\
\text { mobile phone market of Zimbabwe. }\end{array}$ & Rejected \\
\hline H3 & $\begin{array}{l}\text { There is no correlation between price and customer satisfaction and retention in mobile } \\
\text { phone market of Zimbabwe. }\end{array}$ & Rejected \\
\hline H4 & $\begin{array}{l}\text { There is no correlation between penetration marketing and customer satisfaction and } \\
\text { retention in mobile market of Zimbabwe. }\end{array}$ & Rejected \\
\hline H5 & $\begin{array}{l}\text { There is no correlation between loyalty programs and customer satisfaction and retention } \\
\text { in the mobile phone industry of Zimbabwe. }\end{array}$ & Rejected \\
There is no correlation between communication and customer satisfaction and retention & Rejected \\
\hline
\end{tabular}

Conclusions, recommendations and future areas of research

The study analysed the retention strategies used by Zimbabwean mobile service providers to evaluate their impact on customer retention, that is examining the factors that influence customer prefer of certain mobile service provider when the switching costs are so low. The switching barriers such as the cost of a Simcardare now very low, simcard now costing $\$ 1$ for two in some instance and from the analysis the majority of customers have more than one line either from different service providers. Econet has tried to put in switching barriers in the form of brand name, creating psychological bonds with the customer. Econet tries to satisfy its customersand also exceed their expectations. This is supported by the large number of customers who subscribed to Econet (80\%). Several authors argue that even customers may switch if their alternatives elsewhere (Richards, 1996; Patterson and Smith, 2000).

Six independent variables were examined, service quality; customer care; pricing; penetration marketing /other services; loyalty programs and communication. The research observed that mobile service providers offer a range of services to customers but only one service provider Econet seem to outcompete the other two, Telecel and Netone. The factors observed as influencing preference of service provider in the Zimbabwean market the least preferred were, customer information updates, with a correlation of (0.673); availability of service shops,(503), and efficient network (0.484); availability of recharge cards (0.469). The least preferred were observed to be, toll free numbers $(0.281)$, advance air time $(0.311)$; and used by many which pertain to the image of the organisation (0.306). But it must be noted that correlations of all the variable factors ranged from weak to moderate relationships. The research therefore concludes that the variable factors observed have positive impact on customer retention in the Zimbabwean mobile phone industry.

\section{Recommendations}

Service providers should continue using the strategies they are using but need to be worry of enhancing customer value since it is the sustainable basis for retaining customer and hedging the market. Price is critical factor in this industry, for both call charges and other services since it influences preference and usage rate. 


\section{Future research}

Future research must focus on researches with larger samples and to include all the three service providers.

\section{References}

[1]. Adeleke, A., and Aminu, S.A. (2012), "The Determinants of Customer Loyalty in Nigeria's GSM Market", International journal of Business and Social Science, Vol.3 No.14, pp.209-222.

[2]. Anderson, E. W., Fornell, C. and Lehmann, D. R. (1994), 'Customer satisfaction, market share, and profitability: Findings from Sweden'. Journal of Marketing 58, 53-66.

[3]. Bolton, R. N. (1998), "A dynamic model of the duration of the customer's relationship with a continuous service provider: The role of satisfaction”, Marketing Science, Vol. 17 No.1, pp. 45-65.

[4]. Bolton, R.N. and Lemon, K. N. (1999), 'A dynamic model of customers' usage of services: Usage as an antecedent and consequence of satisfaction'. Journal of Marketing Research Vol. 36 No.2, pp.171-186.

[5]. Buttle, F. (2008), Customer Relationship Management Concepts and Technologies Second edition, Butterworth, USA.

[6]. Crossby, L.A., Evans, K.R.and Cowles, D. (1990),"Relationship quality in Services: An interpersonal influence perspective. The Journal of Marketing, Vol.54 pp.68-81.

[7]. Gronroos, C.(2004), "The relationship marketing process :Communication ,Interaction,Dialogue,Value”,Journal of Business and Industrial Marketing,Vol.19 No.2,pp.99-113.

[8]. Gronroos,C. (1994),From marketing mix to relationship marketing towards a paradigm shifting Marketing,Mnagemenet Decisions, Vol,32 No.2,pp.4-20.

[9]. Gummesson, E. (2008) Total Relationship Marketing management, relationship strategy, CRM and a new dominant logic for the value -creating network. Third Edition, Butterworth, UK.

[10]. Gustafsson, A., M. D. J and Roos,I. (2005), 'The effects of customer satisfaction, relationship commitment dimensions, and triggers on customer retention'. Journal of Marketing, 69, pp.210-218.

[11]. Hildago,P., Manzur,E., Olavarrieta,S., and Farias,P.(2008), “Customer retention and price matching: The AFPs case', Journal of Business Research,Vol.61,pp.691-696

[12]. Kollmann, T. (2000), "The price/acceptance function: Perspective s of a pricing policy in European telecommunication markets", European Journal of Innovation Management, Vol.3 No.1, pp.7-14.

[13]. Monroe,K.B.(1991),Pricing-making profitable decisisons,New York, McGraw-Hill

[14]. Morgan, R. M and Hunt, S. D. (1994) The Commitment -trust theory of relationship marketing, Journal of marketing, 58 (July), pp 20-38.

[15]. Oliver, R.L. ( 1997 ) Satisfaction: a behavioural perspective on the consumer, McGraw-Hill International ,Singapore

[16]. Parker, and Mathews, B.P. (2001), "Customer satisfaction: contrasting academic and consumer interpretations", Marketing Intelligence and Planning, Vol.19 No.1, pp. 38-44.

[17]. POTRAZ (2011) Zimbabwe's current mobile subscriber stats www.techzim.co.zw.2011/zimbabwe current mobile subscriber- stats2011 (Accessed on 29.03.20130

[18]. Ralston, R.W. (2003), "The effects of customer service, branding and price on the perceived value of local telephone service", Journal of Business Research, Vol.52, pp.201-213.

[19]. Ranaweera, C. and Neely, A. (2003),"Some moderating effects on the service quality -customer retention link", International journal of operations and production management, Vol.23 No.2, pp.230-248.

[20]. Ranaweera, C. and Prabhu, J. (2003), "The influence of satisfaction, trust and switching barriers on customer retention in a continuous purchasing setting", The International Journal of service industry management, Vol. 14, No.4, pp.374-395.

[21]. Reichheld, F.F. and Sasser .W.E.(1990),Zero defections :Quality comes from Services ,Harvard Business Review , Vol.68 No.5,pp.105 -111.

[22]. Reichheld, F.F.(1996),Learning from customers defections, Harvard Business Review, March -April ,pp.56-69

[23]. Richards, T. (1996), "Using the conversion model to optimise customer retention", Managing Service Quality, Vol.6, No.4, pp.48-52.

[24]. Sharma, N., and Patterson, P.G. (1999), "A model of relationship commitment among professional services", Journal of services marketing, Vol.13 No.2, pp.151-170.

[25]. Sharma, N., and Patterson, P.G.(2000), "Switching costs, alternative attractiveness and experience as moderators of relationship commitment in professional, consumer services", International journal of service industry management,Vol.11 No.5,pp470-490.

[26]. Villanueva, J. and Hanssens, D.M. (2007), Customer Equity: Measurement, Management and Research Opportunities

[27]. Zeithaml, V.A., Berry, L.L., and Parasuraman, A. (1996),'The behavioural consequences of service quality", Journal of Marketing,Vol.60,pp.31-46. 